INDEPENDENT JOURNAL OF MANAGEMENT \& PRODUCTION (IJM\&P)

http://www.ijmp.jor.br

v. 12, n. 8, November-December 2021

ISSN: 2236-269X

DOI: 10.14807/ijmp.v12i8.1518

\title{
EVALUATION OF OCCUPATIONAL SAFETY CONDITIONS IN A WASTE PLASTIC RECYCLING PLANT IN BRAZIL
}

\author{
Bruna Borges Soares \\ Universidade Federal do Sul da Bahia, Brazil \\ E-mail: soaresborges.b@gmail.com \\ Lucas Farias de Sousa \\ Universidade Estadual de Santa Cruz, Brazil \\ E-mail: eng.sousalucas@gmail.com \\ Mariana Aguiar dos Santos \\ Universidade Estadual do Sudoeste da Bahia, Brazil \\ E-mail: marianaaguiar2009.1@hotmail.com
}

Submission: 12/9/2020

Revision: $1 / 8 / 2021$

Accept: 1/20/2021

\section{ABSTRACT}

The adequacy of working conditions to safety standards has a fundamental importance in the company's environment. The efficient implementation of an Occupational Health and Safety Management System allows the reduction of risks associated with accidents; reduce costs to the employer and a strong ally in the competitive market when the safety indicator is a decisive factor in the choice of suppliers. The aim of this study was to evaluate occupational safety and health $(\mathrm{OSH})$ practices at work in a plastic recycling plant located in northeastern Brazil, as well as to identify opportunities for improvement. Data collection was carried out from on-site visits and control measures were proposed for the risk factors identified. The evaluation made it possible to identify that the recycling activity is characterized by several occupational hazards, which are aggravated by inadequate working conditions. The non-conformity of jobs, the use of obsolete equipment and the lack of specific training to perform certain functions were identified as the most relevant aspects. For these, opportunities for improvement and adequation were connected. The study results can help other companies that perform the same activities to improve their performance in $\mathrm{OSH}$ based on the points of improvement presented.

Keywords: Occupational Safety and Health, Occupational Hazards, Labor Practices, Individual Protection Equipment, Work Accident 
DOI: 10.14807/ijmp.v12i8.1518

\section{INTRODUCTION}

Plastic is synthetic polymer highly flexible, which can be heated, formed and molded into different ways (Gulseven et al., 2019). It has many valuable uses, which makes humanity very dependent on it. In consequence, the waste plastic generation has been increasing worldwide. It is estimated that 500 billion plastic bags were used each year and, from all of the consumer plastics, 50\% was designed to be thrown away after being used only once (UNEP, 2018).

Thereby, one way to reduce the heavy plastic load on the planet is the material recovery from recycling. The most common method of recycling is called mechanical (Goodship, 2007). It consists of a number of operations such as material separating, fragmentation (grinding), washing and separation, drying, extrusion, as well as the transformation of the raw material recycled by the processing industries (Soto et al., 2018). These activities can present several hazards occupational for employees, compromising their safety and health.

In addition, accidents at work can cause irreversible damage to the assets, resources and reputation of the affected organizations (Aburumman, Newnam \& Fildes, 2019). According to the Ministry of Finance, in 2017, were recorded 549,405 accidents in Brazil (AEAT, 2017) including accidents registered as typical, commuting and occupational disease; and those without registration (report of accident at work). However, these numbers can be many times higher than those captured.

Occupational Health and Safety (OHS) is not restricted to the technical order of prevention and/or repair of occupational accidents. It is an indicator of social sustainability (Hutchins \& Sutherland, 2008) and a fundamental component of the elements that integrate the responsibility of organizations. Thus, good performance in $\mathrm{OSH}$ is decisive for the success of companies. Besides reducing the risk of accidents, this system promotes the health and satisfaction of workers, improve the operating results and the image of the organization, creating new market opportunities (Oliveira, Oliveira \& Almeida, 2010), especially when issues related to safety are decisive factors.

The cases of accident and death at the workplace are directly associated with the bad OSH management or no application standard (either through negligence or malpractice), causing exposure of the employees to routine exercises of gestures, postures and mental activities that can cause overload. This also happens in recycling plants, especially in places where regulation is flawed or low enforced. 
INDEPENDENT JOURNAL OF MANAGEMENT \& PRODUCTION (IJM\&P)

http://www.ijmp.jor.br

v. 12, n. 8, November-December 2021

ISSN: $2236-269 X$

DOI: $10.14807 /$ ijmp.v12i8.1518

The identification of occupational risks in the work environment is the first step to minimize or even eliminate occupational risks. Therefore, the present study aimed to identify and qualitatively assess the occupational risks in a plastic recycling plant located in northeastern Brazil, besides suggest control measures for the critical points (risk factors) identified.

\section{LITERATURE REVIEW}

There are many risks associated with the recycling sector. In a systematic review of published literature and two UK databases, Poole and Basu (2017) identified health risks, biological effects and occupational diseases of waste and recycling workers. The heavy manual labor, as well as exposure to bioaerosols, heavy metals and organic pollutants, were the main occupational hazards mentioned.

When recycling plants are compared with other solid waste management facilities (as an example sanitary landfills, transfer stations, mechanical-biological treatment plants and HealthCare Waste incinerators), this can be even more worrying. Kontogianni and Moussiopoulos (2017) applied structured questionnaires and interviews with safety officers and workers at solid waste management facilities and observed that, among them, material recovery was one of those activities with the highest risk level.

Neitzel et al. (2013) observed that, among the risks that the scrap recycling workers are exposed, can be cited substantial noise exposures, traffic accidents, unsafe work surfaces, lacerations/abrasions, repetitive postures and movements. These physical, chemical, biological, ergonomic and physical risks are listed and studied by other authors as well.

Burns et al. (2016) characterized the noise levels experienced by e-waste recycling workers in Ghana. The results indicated that workers exposed to noise levels above the recommended level presented relatively common hearing difficulties, moderate to high levels of stress, as well as several numbers of symptoms (for example, dizziness and shortness of breath) that may indicate cardiovascular problems.

In a study carried out in Quebec recycling plants, the authors identified ergonomic risks were related to back pain, due to the inadequate postures adopted in handling objects. According to the authors, the movements, the posture of the 6worker and the effort required to carry out the activities are sources of tension, particularly in the arms, back, shoulders and wrist (Lavoie \& Guertin, 2001). Cockell et al. (2004) also identified sources of discomfort in a 
DOI: 10.14807/ijmp.v12i8.1518

sorting sector of a cooperative formed by recyclable material collectors, such as movement restriction, extreme movements of the shoulder and spine.

Concerning occupational accident risks, according to Lavoie and Guertin (2001), cuts on hands and forearms are common in waste recycling plants. Cioca et al. (2018) checked that there is risk of cuts during the manual separation of materials, since the waste may contain impurities and materials that are not suitable for separation (especially in the first stage). The authors point out that the use of personal protective equipment can reduce the risks associated with the process, as well as the implementation of the mechanical separation system.

Thus, a situation of non-safety in labor occupations has a direct personal impact, once it can cause physical and psychological weakness in employees and decrease their work capacity. This also generates a chain of problems for their families, the company, the government and society (Pie et al, 2020).

\section{METHODOLOGY}

\subsection{Research method and data gathering procedure}

The study was conducted in a recycling plant located in the Northeastern of Brazil. The data collected were about the environmental and occupational hazards of the plant (physical, chemical, biological, ergonomic and accident) through a checklist and consultation of company files during visits in loco between June to August 2019.

The activities evaluated were those related to the manufacture of recycled products (Figure 1), as follows: primary screening, secondary screening, grinding, washing and drying, agglutination, granules extrusion, extrusion of ecological stake. The Transport of raw material and finished products, as well as the maintenance activities and production coordination are also included.

The risk factors were analyzed separately for each of these activities. They were identified and assessed for source, time of exposure, as well as trajectory and propagation of agents. The control document of the Environmental Risk Prevention Program (PPRA) was used as a supporting material. From this information and existing control measures (administrative, collective and individual) proposed improvements, based on regulatory standards on health and safety at work.

\subsection{Location and characteristics of the case study}


INDEPENDENT JOURNAL OF MANAGEMENT \& PRODUCTION (IJM\&P)

http://www.ijmp.jor.br

v. 12, n. 8, November-December 2021

ISSN: 2236-269X

DOI: $10.14807 /$ ijmp.v12i8.1518

The main economic activity of the company is the conversion and recovery of postconsumer waste plastic in recycled products (bags and ecological stake). The company has been in operation since 2001 and 29 employees that work 40-hour workweek. The total plant area is $14,500 \mathrm{~m}^{2}$, approximately $10 \%$ of built area. Comprises an office, a sorting area, a production hall, a greenhouse and a wash tank area. Ventilation and lighting occur naturally (for the latter there is an artificial supply when necessary).

The machinery used in the recycling process are agglutination machine, extruders, milling machines, press machines, plastic chippers, wash tank and dryers. In this study, the risks associated with the production of ecological stakes and the recycled granules were included. The manufacture of recycled bags was not included, although all the processes described here are part of their production process.

\subsection{Description of the manufacture of recycled products}

The following description was based on on-site visits to a recycling plant where the case study was conducted. It is a description of all the steps that make up the production process. The processes may be or not specific to this particular industry.

1) Transport: The employee transports, collects and delivers cargo in general. It is also responsible for inspection of the vehicle and cargo, their documentation, as well as defining routes and regularizing transportation. This activity is realized sitting with the movement of the arms and legs.

2) Primary screening: The employee transports the bales of plastic scraps from the unloading sector to the sorting sector (with the aid of a wheelbarrow). On a table, it separates the material by type and color, puts it in bags and deposits them close to the grinding sector. This activity is performed standing with movements of arms and legs.

3) Grinding, washing and drying: The employee places scraps and plastic lees in the mill. The material is fragmented and transported automatically through tubes to the wash tank. After washing, it is mechanically dry (through a suitably designed drier) and forwarded to the greenhouse (a suitably designed drier is used). Then, the plastic material is placed in bags. This activity is performed standing with movements of arms and legs.

4) Agglutination: The employee transports the bag by crane (with clean plastic material) to the work platform. He fills the agglutination machine manually and adds water progressively. In this step, the material is homogenized. Then, is removed from the 
DOI: 10.14807/ijmp.v12i8.1518

machine and transported with a wheelbarrow to the extrusion sector. Beyond the homogenized material, the process also generates a residual plastic (lees) that is headed to secondary screening and reprocessed. This activity of agglutination is performed standing with movements of arms and legs.

5) Secondary screening: This stage happens with the residual plastic of agglutination (lees). The employee shares the lees generated into several smaller pieces, with the aid of an ax/or a chainsaw and place them in a bag. The bag is then transported to the grinding, washing and drying stage (stage 3) where the material is reprocessed. The activity has as characteristics of an intense work of the arms and trunk, since it loads and saws the lees manually, raises and/or pushes significant heavy loads.

6) Granules extrusion: The employee collects the agglutinated plastic with a bucket and fills the extruder funnel in the platform. The material is melted, forming hot threads that are subsequently cooling in a basin by an automated process. Then, taken to the shredder where the beans are ready for bagging come out. The activity is performed standing with movements of legs and arms.

7) Ecological stake extrusion: The employee collects the agglutinated plastic material, goes up in the platform and, with the aid of a bucket, puts the material in the funnel of the extruder where is melted automatically. The employee fills the mold/form with the melted plastic, directs it to the press. Then, is cooled in a cooling basin. The ecological stake is unmolded and stored in the expedition sector. The mains characteristics of the activity are intense work of the arms and trunk with leg movements.

8) Maintenance activities: The employee performs preventive and corrective maintenance on equipment and machines on-site or in the workshop. Sporadically performs welding, cutting and painting. The activity is performed standing with movements of legs and arms. The main characteristic of the activity is standing work with movements of legs and arms.

9) Production coordination: The employee coordinates the team, monitors quality and production, participates in meetings, and the implementation of new projects. The main characteristics of this activity are standing and sitting work with few movements of arms and legs. 


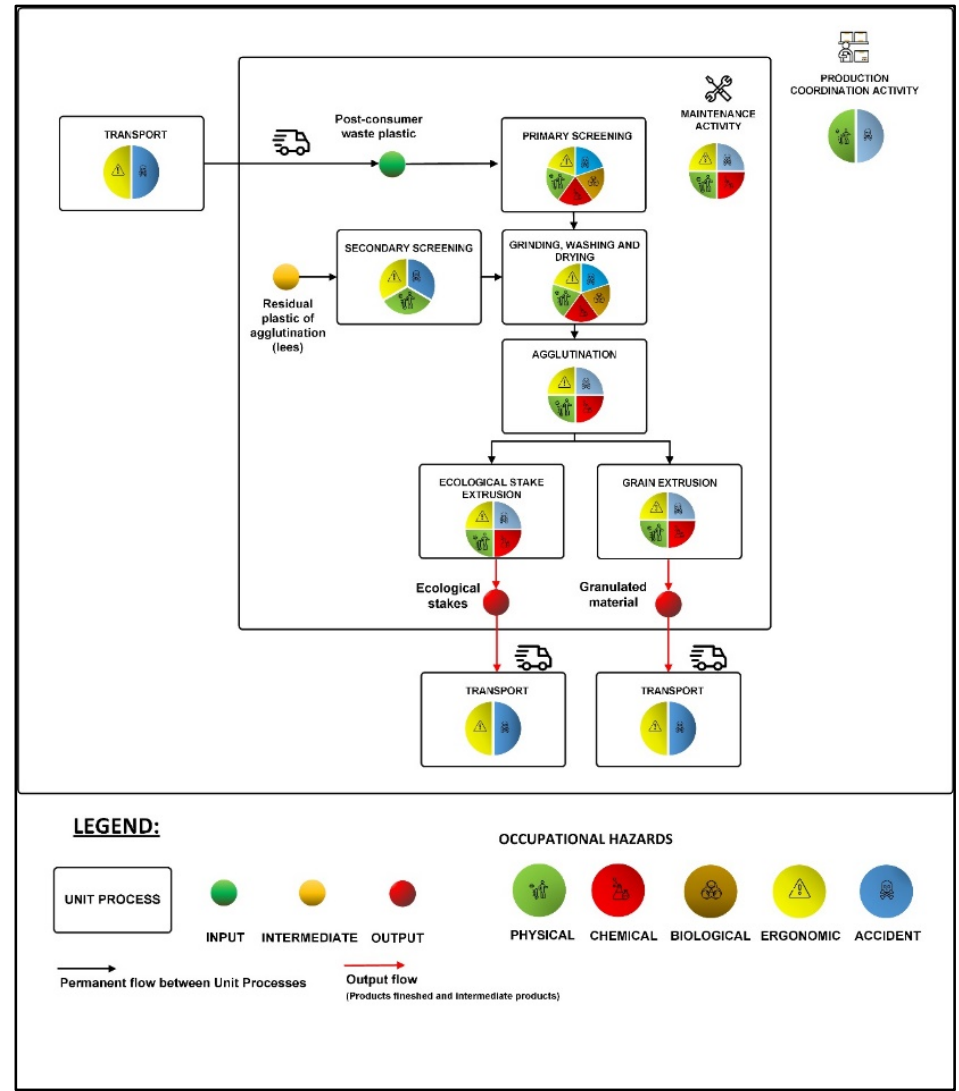

Figure 1: Fluxogram of the process and identification of occupational hazards.

\section{RESULTS AND DISCUSSION}

The main activities, occupational hazard agents, possible damage to health, existing control measures and proposed presented are included in Table 1.

All the activities analyzed showed occupational hazard agents influenced by several factors. This signals the importance of health and safety at work in the execution of activities related to the recycling of materials.

Table 1: Occupational hazard identified in the recycling plant, possible damage to health, existing control measures and proposed

\begin{tabular}{|c|c|c|c|c|}
\hline Activities & Hazard factors & $\begin{array}{c}\text { Possible damage } \\
\text { to health }\end{array}$ & $\begin{array}{c}\text { Existing control } \\
\text { measures }\end{array}$ & $\begin{array}{l}\text { Proposed control } \\
\text { measures }\end{array}$ \\
\hline \multicolumn{5}{|c|}{ Physical Occupational Risk } \\
\hline Primary & \multirow{5}{*}{ Exposure to noise } & \multirow{5}{*}{$\begin{array}{l}\text { Hearing loss, } \\
\text { irritation, } \\
\text { insomnia, lack of } \\
\text { appetite and } \\
\text { headaches }\end{array}$} & \multirow{5}{*}{$\begin{array}{l}\text { Use of PPE (hearing } \\
\text { protection) and } \\
\text { reduction of exposure } \\
\text { time in Primary } \\
\text { screening activities } \\
\text { and Grinding, } \\
\text { washing and drying }\end{array}$} & Maintain existing control \\
\hline screening & & & & measures, as well as, \\
\hline $\begin{array}{c}\text { Grinding, } \\
\text { washing and }\end{array}$ & & & & $\begin{array}{l}\text { conduct training, periodic } \\
\text { inspection of the use of PPE, }\end{array}$ \\
\hline drying & & & & an inspection of noisy \\
\hline $\begin{array}{l}\text { Secondary } \\
\text { screening }\end{array}$ & & & & $\begin{array}{l}\text { machines, quantitative } \\
\text { assessment of the noise and } \\
\text { reduced exposure time in } \\
\text { secondary screening } \\
\text { activity. }\end{array}$ \\
\hline $\begin{array}{c}\text { Agglutination } \\
\text { Granules }\end{array}$ & $\begin{array}{l}\text { Exposure to noise } \\
\text { and heat }\end{array}$ & $\begin{array}{l}\text { Hearing loss, } \\
\text { irritation, }\end{array}$ & $\begin{array}{l}\text { Use of PPE (shell- } \\
\text { type and plug-type }\end{array}$ & $\begin{array}{l}\text { Maintain existing control } \\
\text { measures, training, periodic }\end{array}$ \\
\hline
\end{tabular}


INDEPENDENT JOURNAL OF MANAGEMENT \& PRODUCTION (IJM\&P)

http://www.ijmp.jor.br

v. 12, n. 8, November-December 2021

ISSN: 2236-269X

DOI: 10.14807/ijmp.v12i8.1518

\begin{tabular}{ccc}
\hline extrusion & insomnia, & hearing protector), \\
headaches and & dehydration \\
natural ventilation & and 15 minutes rest \\
exhaustion & (break)
\end{tabular}

$\begin{array}{ccc}\text { Hearing loss, } & \begin{array}{c}\text { irritation, } \\ \text { insomnia, } \\ \text { headaches, } \\ \text { dermatitis and } \\ \text { stake extrusion }\end{array} & \begin{array}{c}\text { Exposure to noise, } \\ \text { humidity and heat }\end{array}\end{array}$

\begin{tabular}{ccc}
\hline $\begin{array}{c}\text { Maintenance } \\
\text { activities }\end{array}$ & $\begin{array}{c}\text { Exposure to noise } \\
\text { and non-ionizing } \\
\text { radiation }\end{array}$ & $\begin{array}{c}\text { Hearing loss, } \\
\text { irritation, } \\
\text { insomnia, } \\
\text { headaches, } \\
\text { dermatitis and } \\
\text { burns }\end{array}$ \\
\hline $\begin{array}{c}\text { Production } \\
\text { coordination }\end{array}$ & Exposure to noise & $\begin{array}{c}\text { Hearing loss, } \\
\text { irritation, } \\
\text { insomnia, } \\
\text { headaches and } \\
\text { burns }\end{array}$ \\
$\begin{array}{c}\text { Chemical Occupational Risk } \\
\text { Primary } \\
\text { screening }\end{array}$ & & \\
\cline { 1 - 2 } $\begin{array}{c}\text { Grinding, } \\
\text { washing and } \\
\text { drying }\end{array}$ & Breathable Dust & $\begin{array}{c}\text { Irritation of eyes } \\
\text { and respiratory } \\
\text { system }\end{array}$ \\
& &
\end{tabular}

\begin{tabular}{c}
\hline Agglutination \\
\hline $\begin{array}{c}\text { Granules } \\
\text { extrusion }\end{array}$ \\
\hline
\end{tabular}

Ecological stake extrusion

Plastic dust and fumes
Irritation of the eyes, respiratory system and neurological disorders
Reduction of exposure time, use of PPE (shell and plug hearing protector), use of waterproof glove and natural ventilation inspection of the use of PPE, an inspection of noisy machines, quantitative assessment of the noise and increase natural ventilation and/or artificial ventilation with the installation of fans. Maintain existing control measures, training, periodic inspection of the use of PPE, an inspection of noisy machines, quantitative assessment of noise and heat, and increase natural ventilation and/or installation of artificial ventilation.

\section{Reduction of}

exposure time, use of

PPE, such as shell and plug hearing protector, welding mask, safety glasses, uniform and glove

Maintain existing control measures and inspection of the use of PPE.

Use of PPE (hearing protection)

Maintain existing control measures and inspection of the use of PPE.
Training and use of PPE such as safety glasses, fold-flat dust Masks in primary screening activities and Type PFF1 respirators (minimum efficiency of 80\%) in Grinding, washing and drying activitys Training and use of PPE such as safety glasses, type PFF1 Maintain existing control respirators (minimum measures, install exhaust efficiency of 80\%) fans and a lid on the and type PFF2 agglutination machines, respirators (minimum periodic inspection of the efficiency of 94\%) for use of PPE and increase the Granules extrusion ventilation of the workplace. and Ecological stake extrusion.

Use of PPE, such as safety glasses, type PFF1 respirators
Irritation of the eyes and

Maintenance Dust, metal fumes, respiratory system, activities oils and greases neurological

disorders and metal intoxication
Maintain existing control measures and install a cover on the mill filling opening (Maintain existing control measures and install a cover on the mill filling opening (in supply). (minimum efficiency of $80 \%$ ) and PFF2

Maintain existing control (minimum efficiency measures, periodic inspection of the use of PPE of $94 \%$ ), welding and increase the ventilation of the workplace. 
INDEPENDENT JOURNAL OF MANAGEMENT \& PRODUCTION (IJM\&P)

http://www.ijmp.jor.br

v. 12, n. 8, November-December 2021

ISSN: 2236-269X

DOI: 10.14807/ijmp.v12i8.1518

\begin{tabular}{|c|c|c|c|c|}
\hline \multicolumn{5}{|c|}{ Biological Occupational Risk } \\
\hline $\begin{array}{l}\text { Grinding, } \\
\text { washing and } \\
\text { drying }\end{array}$ & Microorganisms & $\begin{array}{c}\text { Dermatitis and } \\
\text { infectious diseases }\end{array}$ & $\begin{array}{l}\text { Use of PPE, such as a } \\
\text { waterproof glove, } \\
\text { PVC apron, rubber } \\
\text { boot, long sleeve } \\
\text { shirt, type PFF1 } \\
\text { respirators (minimum } \\
\text { efficiency of 80\%) } \\
\text { and use of alcohol for } \\
\text { cleaning } \\
\end{array}$ & $\begin{array}{l}\text { Maintain existing control } \\
\text { measures, specific training } \\
\text { and periodic inspection of } \\
\text { PPE. }\end{array}$ \\
\hline \multicolumn{5}{|c|}{ Ergonomic Occupational Risk } \\
\hline Transport & $\begin{array}{l}\text { Extreme posture - } \\
\text { activity performed } \\
\text { for a long period in } \\
\text { the same position } \\
\text { (sitting) }\end{array}$ & $\begin{array}{c}\text { Loss of } \\
\text { neuromuscular } \\
\text { and/or } \\
\text { osteoarticular } \\
\text { functions } \\
\end{array}$ & $\begin{array}{c}\text { Training, seat } \\
\text { adjustment, routine } \\
\text { vehicle inspection and } \\
\text { rest stops }\end{array}$ & $\begin{array}{l}\text { Maintain existing control } \\
\text { measures. }\end{array}$ \\
\hline \multirow{2}{*}{$\begin{array}{l}\text { Primary } \\
\text { screening }\end{array}$} & $\begin{array}{c}\text { Requirement of } \\
\text { physical effort } \\
\text { (manual transport of } \\
\text { bales) }\end{array}$ & $\begin{array}{l}\text { Loss of } \\
\text { neuromuscular } \\
\text { and/or } \\
\text { osteoarticular } \\
\text { functions }\end{array}$ & $\begin{array}{l}\text { Use of a pallet truck } \\
\text { and manual trolley, } \\
\text { manual cargo } \\
\text { transport training and } \\
15 \text { minutes rest } \\
\text { (break) }\end{array}$ & $\begin{array}{l}\text { Maintain existing control } \\
\text { measures, the suitability of } \\
\text { the floor, mechanization the } \\
\text { transport of bales and } \\
\text { purchase of more modern } \\
\text { pallet truck. }\end{array}$ \\
\hline & $\begin{array}{l}\text { Extreme/forced } \\
\text { posture (activity } \\
\text { performed for a long } \\
\text { period in the same } \\
\text { position, standing). }\end{array}$ & $\begin{array}{c}\text { Loss of } \\
\text { neuromuscular } \\
\text { and/or } \\
\text { osteoarticular } \\
\text { functions } \\
\end{array}$ & $\begin{array}{l}\text { Installation of the } \\
\text { seats in places where } \\
\text { employees can use } \\
\text { during breaks and 15- } \\
\text { minute pause }\end{array}$ & $\begin{array}{l}\text { Maintain existing control } \\
\text { measures. }\end{array}$ \\
\hline \multirow{2}{*}{$\begin{array}{l}\text { Grinding, } \\
\text { washing and } \\
\text { drying }\end{array}$} & $\begin{array}{l}\text { Physical effort } \\
\text { requirement } \\
\text { (strength) }\end{array}$ & $\begin{array}{c}\text { Loss of } \\
\text { neuromuscular } \\
\text { and/or } \\
\text { osteoarticular } \\
\text { functions } \\
\end{array}$ & $\begin{array}{l}\text { Training, use of pallet } \\
\text { truck and } 15 \text { minutes } \\
\text { rest (break) }\end{array}$ & $\begin{array}{l}\text { Maintain existing control } \\
\text { measures, mechanize the } \\
\text { transport of bags and } \\
\text { purchase more modern } \\
\text { pallet trucks. }\end{array}$ \\
\hline & $\begin{array}{l}\text { Uncomfortable } \\
\text { posture adopted in } \\
\text { the carrying out the } \\
\text { activity (removing } \\
\text { scraps from bags } \\
\text { and filling the mill) }\end{array}$ & $\begin{array}{l}\text { Loss of } \\
\text { neuromuscular } \\
\text { and/or } \\
\text { osteoarticular } \\
\text { functions }\end{array}$ & $\begin{array}{l}\text { Training and } 15 \\
\text { minutes rest (break) }\end{array}$ & $\begin{array}{l}\text { Install a } 70 \mathrm{~cm} \text { wooden } \\
\text { structure to position the bag } \\
\text { when filling the mill. }\end{array}$ \\
\hline Agglutination & $\begin{array}{l}\text { Physical effort } \\
\text { requirement } \\
\text { (strength) }\end{array}$ & $\begin{array}{l}\text { Loss of } \\
\text { neuromuscular } \\
\text { and/or } \\
\text { osteoarticular } \\
\text { functions } \\
\end{array}$ & $\begin{array}{l}\text { Automatic pulleys, } \\
\text { use of pallet trucks, } \\
\text { help from other } \\
\text { employees and } \\
\text { training } \\
\end{array}$ & $\begin{array}{l}\text { Maintain existing control } \\
\text { measures and purchase of } \\
\text { more modern pallet trucks. }\end{array}$ \\
\hline \multirow{2}{*}{$\begin{array}{l}\text { Secondary } \\
\text { screening }\end{array}$} & $\begin{array}{l}\text { Extreme/forced } \\
\text { posture (activity } \\
\text { performed for a long } \\
\text { period in the same } \\
\text { position, standing) } \\
\end{array}$ & $\begin{array}{c}\text { Loss of } \\
\text { neuromuscular } \\
\text { and/or } \\
\text { osteoarticular } \\
\text { functions } \\
\end{array}$ & Training & $\begin{array}{l}\text { Maintain existing control } \\
\text { measures and adjust } \\
\text { workbench to the height of } \\
\text { the employee. }\end{array}$ \\
\hline & $\begin{array}{c}\text { Requirement of } \\
\text { physical effort } \\
\text { (manual transport of } \\
\text { bales) }\end{array}$ & $\begin{array}{l}\text { Loss of } \\
\text { neuromuscular } \\
\text { and/or } \\
\text { osteoarticular } \\
\text { functions } \\
\end{array}$ & $\begin{array}{c}\text { Use of pallet truck } \\
\text { and manual cart, help } \\
\text { from other employees } \\
\text { and training }\end{array}$ & $\begin{array}{l}\text { Maintain existing control } \\
\text { measures and mechanize the } \\
\text { transport of bales. }\end{array}$ \\
\hline $\begin{array}{l}\text { Granules } \\
\text { extrusion }\end{array}$ & $\begin{array}{l}\text { Requirement of } \\
\text { physical effort } \\
\text { (lifting and manual } \\
\text { transport of weight } \\
\text { to supply the } \\
\text { extruder) } \\
\end{array}$ & $\begin{array}{l}\text { Loss of } \\
\text { neuromuscular } \\
\text { and/or } \\
\text { osteoarticular } \\
\text { functions }\end{array}$ & $\begin{array}{l}\text { Training, load } \\
\text { reduction (reducing } \\
\text { the size of the supply } \\
\text { bucket) and } 15 \\
\text { minutes rest (break) }\end{array}$ & $\begin{array}{l}\text { Maintain existing control } \\
\text { measures. }\end{array}$ \\
\hline
\end{tabular}


INDEPENDENT JOURNAL OF MANAGEMENT \& PRODUCTION (IJM\&P)

http://www.ijmp.jor.br

v. 12, n. 8, November-December 2021

ISSN: 2236-269X

DOI: 10.14807/ijmp.v12i8.1518

\section{Ecological}

stake extrusion

$\begin{array}{ccc} & \begin{array}{c}\text { Physical effort } \\ \text { requirement } \\ \text { (strength) }\end{array} & \text { Loss of } \\ & \text { neuromuscular } \\ \text { Maintenance } & \begin{array}{c}\text { Physical effort } \\ \text { activities }\end{array} & \text { and/or } \\ & \begin{array}{c}\text { requirement } \\ \text { (strength) }\end{array} & \text { functions }\end{array}$

Training, 15 minutes rest (break) in ecological stake extrusion activity and change the location of the use of manual trolley cooling basin (positioning it and winch of 1,000 at the outlet of the press kilograms in machine) and automatically maintenance services connect the outlet of the press machine shapes to the cooling basin.

\begin{tabular}{|c|c|c|c|c|}
\hline \multicolumn{5}{|c|}{ Accident Occupational Risk } \\
\hline Transport & Traffic accident & $\begin{array}{l}\text { Polytrauma and } \\
\text { death }\end{array}$ & $\begin{array}{l}\text { Qualification in the } \\
\text { category, inspection } \\
\text { and preventive } \\
\text { maintenance of the } \\
\text { vehicle }\end{array}$ & $\begin{array}{l}\text { Maintain existing control } \\
\text { measures, traffic education } \\
\text { training, periodic inspection } \\
\text { of the blood pressure and } \\
\text { eye. }\end{array}$ \\
\hline $\begin{array}{l}\text { Primary } \\
\text { screening }\end{array}$ & $\begin{array}{l}\text { Contact with } \\
\text { materials, tools and } \\
\text { equipment that can } \\
\text { cause cuts, } \\
\text { excoriation or } \\
\text { perforations }\end{array}$ & $\begin{array}{l}\text { Wounds and } \\
\text { infections }\end{array}$ & $\begin{array}{l}\text { Use of PPE, as a } \\
\text { fabric glove and } \\
\text { safety boot }\end{array}$ & $\begin{array}{l}\text { Protective gloves against } \\
\text { biological and cutting risks, } \\
\text { as well as periodic } \\
\text { inspection of the use of PPE. }\end{array}$ \\
\hline \multirow{2}{*}{$\begin{array}{l}\text { Grinding, } \\
\text { washing and } \\
\text { drying }\end{array}$} & $\begin{array}{l}\text { Contact with } \\
\text { materials, tools and } \\
\text { equipment that can } \\
\text { cause cuts, } \\
\text { excoriation or } \\
\text { perforations } \\
\end{array}$ & $\begin{array}{l}\text { Amputation and } \\
\text { injuries }\end{array}$ & $\begin{array}{l}\text { Accident prevention } \\
\text { training and } \\
\text { protection cap for } \\
\text { razor }\end{array}$ & $\begin{array}{l}\text { Maintain existing control } \\
\text { measures and install an } \\
\text { aperture sensor on the cap of } \\
\text { the razors. }\end{array}$ \\
\hline & $\begin{array}{l}\text { Fall (unevenness of } \\
\text { the grinding } \\
\text { machine supply site) }\end{array}$ & $\begin{array}{l}\text { Polytrauma and } \\
\text { death. }\end{array}$ & Not identified & $\begin{array}{l}\text { Level the worker's place of } \\
\text { displacement and offer } \\
\text { accident } \\
\text { training. }\end{array}$ \\
\hline \multirow[t]{2}{*}{ Agglutination } & $\begin{array}{l}\text { Contact with sharp } \\
\text { equipment (razor of } \\
\text { the agglutination } \\
\text { machine). }\end{array}$ & $\begin{array}{l}\text { Amputation, } \\
\text { excoriation and } \\
\text { injuries }\end{array}$ & $\begin{array}{l}\text { Specific training for } \\
\text { accident prevention }\end{array}$ & $\begin{array}{l}\text { Maintain existing control } \\
\text { measures and adapt the } \\
\text { machine according to NR- } \\
12 \text { standardization. }\end{array}$ \\
\hline & $\begin{array}{l}\text { Fall (platform of the } \\
\text { agglutination } \\
\text { machine) }\end{array}$ & $\begin{array}{l}\text { Polytrauma and } \\
\text { death. }\end{array}$ & Training & $\begin{array}{l}\text { Install safety guard rail on } \\
\text { agglutination machine } \\
\text { platforms. }\end{array}$ \\
\hline $\begin{array}{l}\text { Secondary } \\
\text { screening }\end{array}$ & $\begin{array}{l}\text { Contact with } \\
\text { materials, tools and } \\
\text { equipment that can } \\
\text { cause cuts, } \\
\text { excoriation or } \\
\text { perforations }\end{array}$ & $\begin{array}{l}\text { Amputation and } \\
\text { injuries }\end{array}$ & $\begin{array}{l}\text { Use of PPE, such as } \\
\text { leather glove and } \\
\text { safety boot }\end{array}$ & $\begin{array}{l}\text { Specific training, use of } \\
\text { leather leggings, periodic } \\
\text { inspection of the use of PPE } \\
\text { and adaptation of the } \\
\text { workplace. }\end{array}$ \\
\hline \multirow{3}{*}{$\begin{array}{l}\text { Granules } \\
\text { extrusion }\end{array}$} & $\begin{array}{l}\text { Contact with hot } \\
\text { surfaces }\end{array}$ & $\begin{array}{l}\text { 1st, 2nd and 3rd } \\
\text { degree burn }\end{array}$ & $\begin{array}{l}\text { Training and use of } \\
\text { PPE (glove for high } \\
\text { temperature). }\end{array}$ & $\begin{array}{l}\text { Maintain existing control } \\
\text { measures, thermal } \\
\text { insulation of hot areas of the } \\
\text { machine and periodic } \\
\text { inspection of the use of PPE. }\end{array}$ \\
\hline & $\begin{array}{c}\text { Fall (extruder supply } \\
\text { platform) }\end{array}$ & $\begin{array}{l}\text { Polytrauma and } \\
\text { death. }\end{array}$ & Not identified & $\begin{array}{l}\text { Install safety guard rail on } \\
\text { platforms and stairs }\end{array}$ \\
\hline & $\begin{array}{l}\text { Crushing of upper } \\
\text { limbs (pricking } \\
\text { cylinders). }\end{array}$ & $\begin{array}{l}\text { Amputations, } \\
\text { injuries, bruises } \\
\text { and/or fractures }\end{array}$ & $\begin{array}{l}\text { Training and fixed } \\
\text { protection of the } \\
\text { moving parts of the } \\
\text { pricking machine }\end{array}$ & $\begin{array}{l}\text { Maintain existing control } \\
\text { measures. }\end{array}$ \\
\hline $\begin{array}{c}\text { Ecological } \\
\text { stake extrusion }\end{array}$ & $\begin{array}{c}\text { Fall (extruder supply } \\
\text { platform) }\end{array}$ & $\begin{array}{c}\text { Polytrauma and } \\
\text { death. }\end{array}$ & Not identified & $\begin{array}{l}\text { Install safety guard rail on } \\
\text { platforms and stairs. }\end{array}$ \\
\hline
\end{tabular}
realized periodic safety inspection. In addition, Ecological stake extrusion

Maintain existing control measures, as well as, (1)

(1)


INDEPENDENT JOURNAL OF MANAGEMENT \& PRODUCTION (IJM\&P)

http://www.ijmp.jor.br

v. 12, n. 8, November-December 2021

ISSN: 2236-269X

DOI: 10.14807/ijmp.v12i8.1518

\begin{tabular}{|c|c|c|c|c|}
\hline & $\begin{array}{l}\text { Crushing of upper } \\
\text { limbs (press } \\
\text { machine). }\end{array}$ & $\begin{array}{l}\text { Amputations, } \\
\text { injuries, bruises } \\
\text { and/or fractures. }\end{array}$ & $\begin{array}{l}\text { Training, bimanual } \\
\text { and simultaneous } \\
\text { activation }\end{array}$ & $\begin{array}{l}\text { Maintain existing control } \\
\text { measures and protect the } \\
\text { side area of the press } \\
\text { machine (leaving only the } \\
\text { opening of the mold-free). }\end{array}$ \\
\hline & $\begin{array}{l}\text { Contact with hot } \\
\text { surfaces }\end{array}$ & Burns & $\begin{array}{l}\text { Training and use of } \\
\text { PPE (leather glove } \\
\text { and knitted fabric } \\
\text { glove) }\end{array}$ & $\begin{array}{l}\text { Maintain existing control } \\
\text { measures, thermally insulate } \\
\text { hot areas, use of high- } \\
\text { temperature gloves by } \\
\text { employees and periodically } \\
\text { inspect the use of PPE. }\end{array}$ \\
\hline \multirow{3}{*}{$\begin{array}{l}\text { Maintenance } \\
\text { activities }\end{array}$} & High level drops & $\begin{array}{l}\text { Polytrauma and } \\
\text { death. }\end{array}$ & $\begin{array}{l}\text { Training and use of } \\
\text { PPE as for safety belt } \\
\text { and helmet }\end{array}$ & $\begin{array}{l}\text { Maintain existing control } \\
\text { measures, periodic } \\
\text { inspection of the use of PPE, } \\
\text { follow standardization NR- } \\
\text { 35, periodic training on } \\
\text { accident prevention and } \\
\text { inspection recurrent of } \\
\text { equipment safety. }\end{array}$ \\
\hline & $\begin{array}{l}\text { Contact with } \\
\text { materials, tools and } \\
\text { equipment that can } \\
\text { cause cuts, } \\
\text { excoriation or } \\
\text { perforations } \\
\end{array}$ & $\begin{array}{l}\text { Amputation and } \\
\text { injuries }\end{array}$ & $\begin{array}{l}\text { Training and use of } \\
\text { PPE, such as gloves } \\
\text { and leather aprons }\end{array}$ & \multirow{2}{*}{$\begin{array}{l}\text { Maintain existing control } \\
\text { measures, accident } \\
\text { prevention training, an } \\
\text { inspection of equipment } \\
\text { safety items and use of PPE } \\
\text { (periodically for all of } \\
\text { them). }\end{array}$} \\
\hline & $\begin{array}{l}\text { Contact with hot } \\
\text { surfaces (blowtorch } \\
\text { handling) }\end{array}$ & Burns & $\begin{array}{l}\text { Training and use of } \\
\text { PPE, such as leather } \\
\text { glove and apron, seat } \\
\text { belt and helmet }\end{array}$ & \\
\hline $\begin{array}{l}\text { Production } \\
\text { coordination }\end{array}$ & $\begin{array}{l}\text { Falling materials, } \\
\text { equipment and } \\
\text { machinery }\end{array}$ & Polytrauma & $\begin{array}{l}\text { Use of PPE (safety } \\
\text { shoe). }\end{array}$ & $\begin{array}{l}\text { Maintain existing control } \\
\text { measures. }\end{array}$ \\
\hline
\end{tabular}

Occupational hazards: Physical (NR-15), Chemical (NR-15), Biological (NR-15), Ergonomic (NR-

17) and Accidental (Law No. 8213/91).

In this study, all 5 types of occupational hazards were observed (physical, chemical, biological, ergonomic and accident).

The most recurrent was the accident risks. They were present in all activities of the recycling plant, can be offer damage health, since minor injuries, until amputations and death.

Were identified risks of traffic accidents (in the transport activity), contact with sharp materials, hot surfaces, falls risk, as well as crushing of limbs. These risks can be mitigated through the use of Personal Protective Equipment (PPE) and the implementation of structures in specific machines (in order to make their use safer for the employee).

Then, the most frequent occupational hazards were physical and ergonomic. These risks were present in 8 of the 9 activities evaluated. The physical risk was in the most part due to noise exposure, as well as to a lesser extent, exposure to heat, humidity and non-ionizing radiation. 
INDEPENDENT JOURNAL OF MANAGEMENT \& PRODUCTION (IJM\&P)

http://www.ijmp.jor.br

v. 12, n. 8, November-December 2021

ISSN: $2236-269 X$

DOI: $10.14807 /$ ijmp.v12i8.1518

The noise is very common in diverse work environments, including in the recycling industry of other materials (Lavoie \& Guertin, 2001). The exposure above the limits established by the NR-15 standard can cause damage to health, such as hearing loss, irritation, insomnia and headaches. Thus, the implementation of the proposed here measures (training, periodic inspection of the use of PPE and noisy machines) is essential to achieve a greater degree of safety in related activities. However, a more accurate assessment of the exposition of employees must involve quantitative means of measurement (through decibel meter and dosimeter, for example).

The ergonomic risk was evidenced due to inadequate postures, transport of overweight loads, as well as the use of obsolete or ergonomically inadequate machines and equipment. Such situations can lead to loss of neuromuscular and/or osteoarticular functions in the employees.

The chemical risks were present in six evaluated activities. These risks are from fumes generated in the heating of plastic and for shear dust. Carcinogenic, teratogenic, irritating, asphyxiating, anesthetic, allergic effects, among others, are the possible damages caused by dangerous exposure to chemical agents. In addition, according to Cockell et al. (2004), the accumulation of dust and contamination by "remnants" of chemicals present in the collected containers can cause respiratory disorders and allergies.

Among the measures proposed, the installation of exhaust fans and the increase in ventilation at the workplace is the best to be made. Kozajda et al. (2017), at assessing the levels of inhalable dust in waste sorting plants, verified the low level of dust in the facilities were certainly due to efficient ventilation and air conditioning systems. Second Schlosser et al, (2015), the classification rooms must be equipped with a ventilation system that allows operators to work directly under clean and unidirectional airflow.

Ventilation is also an important aspect of thermal comfort (Guimarães et al., 2018). The proposal is also made here for the other sectors that generate dust since the renewal of the air in the environment helps to minimize the concentration of pollutants and contaminants, as well as reduces the transport of biological agents, regardless of the type of management waste plant.

The biological risk is present in two moments: (1) In primary screening and, (2) in joint activities of the grinding, washing, and drying. This risk is due to the contact of the employees with potentially contaminated plastic waste by microorganisms, once the material was obtained 
INDEPENDENT JOURNAL OF MANAGEMENT \& PRODUCTION (IJM\&P)

http://www.ijmp.jor.br

v. 12, n. 8, November-December 2021

ISSN: $2236-269 X$

DOI: 10.14807/ijmp.v12i8.1518

from diverse origins (including material collected from landfills or dumps by third parties) and can offer damage, such as infectious diseases and dermatitis.

Among other agents, humidity conditions in most waste management facilities favor the growth of fungi. Some of these fungi can produce mycotoxins, some of them can be harmful to health (Schlosser et al., 2020). Besides, employees may be exposed to other different pathogenic microorganisms inherent in the handling of plastic waste. Among the control measures proposed, the periodic inspection of the use of PPE and specific training for some workers was repeatedly mentioned.

According to Kontogianni and Moussiopoulos (2017), the "Safety culture" or "safety attitude” is undeniably relevant for achieving a certain degree of safety performance in facilities. Also, the conduction of training courses, as well as the constant presence of safety officers during working hours have great importance, since in case of absence of them can lead to a high level of risk in the installation.

The activities of the factory, due to their characteristics, need constant attention regarding the protection of the employee. Occupational hazards are imminent in all activities carried.

Although there are some practices that the factory still needs greater investment, such as the acquisition of a decibel meter to measure noise in the environment, replacement of obsolete equipment with more modern ones, installation of artificial ventilation and/or increased ventilation natural, installation of complementary safety parts in machines, use of protective gloves against biological risks by employees, adaptation in some jobs post and training for the execution of specific activities.

According to Benite (2004), an ineffective occupational health and safety system are the cause of the costs of occupational accidents. Therefore, there is an inverse relationship between occurred accidents and the costs of non-safety. This require a significant amount of resources whenever an accident occurs. Thus, implementing the measures proposed is the most suitable. These measures can also help other recycling companies that carry similar activities or processes to achieve better performance in OSH.

Safety culture in companies is an important aspect to prevent injuries related to job activities. A job place with a poor safety culture can be characterized by management's failure to recognize or address gaps in their security system (Aburumman, Newnam \& Fildes, 2019). Thus, this type of study (with risk identification) is an important step for OSH in companies. 
DOI: 10.14807/ijmp.v12i8.1518

However, to avoid possible safety problems, in addition to the assessment of potential risks, the recording of previous accident scenarios (level of severity and probability of the event occurring) must be taken into account (Kontogianni \& Moussiopoulos, 2017).

It is important to mention that small companies can find it difficult to manage and effectively control risks at the workplace. Regulations are seen as overly complex to apply and adaptation may require a high investment when are many critical points of security (which need improvements). This challenge is compounded when production processes involve dynamically planned workflows as cited for Shafei et al. (2018). However, it is important to mention that some measures are simple to implement, such as training, inspections of the use of PPE and small adjustments in activities and machines.

Lastly, the cost analysis of other actions proposed can be necessary. This will contribute to its implementation and the establishment of prevention programs aimed at the well-being and safety of employees in the recycling plant.

\section{CONCLUSIONS AND RECOMENDATIONS}

This study allowed us to obtain real results on the working conditions in a plastic waste recycling plant. As far as is known, it is the only work that evaluated occupational hazards related to this segment, since the percentage of recycled plastic material in the world (especially in Brazil) is still small and consequently there are few recycling plants.

The plastic recycling process is characterized by presenting occupational hazards in all functions, with emphasis on accident, physical and ergonomic. The risks are exacerbated by inadequate working conditions, inadequate job position for some activities, obsolete machinery and equipment, as well as the lack of specific safety training for certain functions. An advantage of this recycling sector is the absence of exposure to heavy metals, as in e-waste recycling plants. However, the risks mentioned can also be detrimental to the health and safety of employees.

Some actions are essential to improve the protection of the employees. The preventive and periodic maintenance of machinery, the training of employees regarding safety rules and correct and safe ways of carrying out activities, in addition to the presence of professionals specialized in safety and health in the labor work, contribute to mitigate or even eliminate risks that recycling activities generate for the safety and health of employees.

The adoption of measures proposed is important for the occupational safety and health of the employees. Some actions are easy to implement (in mostly), can generate positive results 
INDEPENDENT JOURNAL OF MANAGEMENT \& PRODUCTION (IJM\&P)

http://www.ijmp.jor.br

v. 12, n. 8, November-December 2021

ISSN: 2236-269X

DOI: 10.14807/ijmp.v12i8.1518

in relation to the increase in performance in $\mathrm{OSH}$, as well as health and motivation gains for the employees. However, it is important to note that in many cases, the implementation of new security initiatives may require a necessary capital investment.

\section{REFERENCES}

Aburumman, M., Newnam, S., \& Fildes, B. (2019). Evaluating the effectiveness of workplace interventions in improving safety culture: A systematic review. Safety science, 115, 376-392.

Benite, A. G. (2004). Sistemas de Gestão da Segurança e Saúde no Trabalho. São Paulo: O Nome da Rosa.

Burns, K., Sun, K., Fobil, J., \& Neitzel, R. (2016). Heart Rate, Stress, and Occupational Noise Exposure among Electronic Waste Recycling Workers. International Journal of Environmental Research and Public Health, 13(1), 140. doi:10.3390/ijerph13010140

Cioca, L. I., Ferronato, N., Viotti, P., Magaril, E., Ragazzi, M., Torretta, V., \& Rada, E. C. (2018). Risk assessment in a materials recycling facility: Perspectives for reducing operational issues. Resources, 7(4), 85. doi.org/10.3390/resources7040085

Cockell, F. F., De Carvalho, A. M. C, Camarotto, J. A, \& Bento, P. E. G. (2004). A triagem de lixo reciclável: análise ergonômica da atividade. Revista Brasileira de Saúde Ocupacional, 29(110), 17-26. doi.org/10.1590/S0303-76572004000200003

Goodship, V. (2007). Plastic recycling. Science Progress, 90(4), 245-268. doi:10.3184/003685007x228748

Guimarães, P. P., Fiedler, N. C., da Silva Oliveira, J. T., Leite, Â. M. P., \& De Souza Lima, J. S. (2018). Análise ergonômica do ambiente de Trabalho na fabricação de ferramentas florestais. Ciência Florestal, 28(4), 1651-1665. doi.org/10.5902/1980509835315

Gulseven, O., Ashkanani, S., Abdullah, S., Ismaeil, H., Alkandari, H., \& Baroun, M. (2019). A sustainable model for enhancing road quality with recycled plastic bags. Kuwait Journal of Science, 46(4), 112-119.

Hutchins, M. J., \& Sutherland, J. W. (2008). An exploration of measures of social sustainability and their application to supply chain decisions. Journal of Cleaner Production, 16(15), 1688-1698. doi:10.1016/j.jclepro.2008.06.001

Kontogianni, S., \& Moussiopoulos, N. (2017). Investigation of the occupational health and safety conditions in Hellenic solid waste management facilities and assessment of the in-situ hazard level. Safety Science, 96, 192-197. doi:10.1016/j.ssci.2017.03.025

Kozajda, A., Jeżak, K., Cyprowski, M., \& Szadkowska-Stańczyk, I. (2017). Inhalable dust, endotoxins and (1-3)- $\beta$-d-glucans as indicators of exposure in waste sorting plant environment. Aerobiologia, 33(4), 481-491. doi:10.1007/s10453-017-9484-4

Lavoie, J., \& Guertin, S. (2001). Evaluation of Health and Safety Risks in Municipal Solid Waste Recycling Plants. Journal of the Air \& Waste Management Association, 51(3), 352-360. doi:10.1080/10473289.2001.10464278

Neitzel, R. L., Crollard, A., Dominguez, C., Stover, B., \& Seixas, N. S. (2013). A mixedmethods evaluation of health and safety hazards at a scrap metal recycling facility. Safety Science, 51(1), 432-440. doi:10.1016/j.ssci.2012.08.012 
Oliveira, O. J. D., Oliveira, A. B. D., \& Almeida, R. A. D. (2010). Gestão da segurança e saúde no trabalho em empresas produtoras de baterias automotivas: um estudo para identificar boas práticas. Revista Produção, 20(3), p. 481-490.

Pie, A. C. S., Fernandes, R. C. P., Carvalho, F. M., \& Porto, L. A. (2020). Presenteeism and associated factors in industry workers. Revista Brasileira de Saúde Ocupacional, 45(13). Epub April 03. doi.org/10.1590/2317-6369000003118

Poole, C. J. M., \& Basu, S. (2017). Systematic Review: Occupational illness in the waste and recycling sector. Occupational Medicine, 67(8), 626-636. doi:10.1093/occmed/kqx153

Schlosser, O., Déportes, I. Z., Facon, B., \& Fromont, E. (2015). Extension of the sorting instructions for household plastic packaging and changes in exposure to bioaerosols at materials recovery facilities. Waste Management, 46, 47-55.

doi:10.1016/j.wasman.2015.05.022

Schlosser, O., Robert, S., \& Noyon, N. (2020). Airborne mycotoxins in waste recycling and recovery facilities: Occupational exposure and health risk assessment. Waste Management, 105, 395-404. doi:10.1016/j.wasman.2020.02.031

Shafei, A., Hodges, J., \& Mayer, S. (2018). Ensuring Workplace Safety in Goal-based Industrial Manufacturing Systems. Procedia Computer Science, 137, p. 90-101. doi:10.1016/j.procs.2018.09.009

Soto, J. M., Blázquez, G., Calero, M., Quesada, L., Godoy, V., \& Martín-Lara, M. Á. (2018). A real case study of mechanical recycling as an alternative for managing of polyethylene plastic film presented in mixed municipal solid waste. Journal of Cleaner Production. doi:10.1016/j.jclepro.2018.08.302

UNEP - United Nations Environment Programme. World Environment Day 2018: Overviewhttps://wedocs.unep.org/bitstream/handle/20.500.11822/25398/WED\%20Messagin g\%20Two-Page\%2027April.pdf?sequence=12\&isAllowed=y 